\title{
THE TOXICITY OF ORALLY ADMINISTERED POTASSIUM SALTS IN RENAL INSUFFICIENCY ${ }^{1}$
}

\author{
By A. W. WINKLER, H. E. HOFF and P. K. SMITH \\ (From the Departments of Internal Medicine, and the Laboratories of Physiology and of \\ Pharmacology, Yale University School of Medicine)
}

(Received for publication August 2, 1940)

Smillie (1) in 1915 reported the sudden collapse of a patient with nephritis seven hours after the oral administration of 10 grams of potassium chloride. He attributed this collapse to an excessive accumulation of potassium in the body owing to impaired excretion. The patient ultimately recovered. Smillie also found that sudden death commonly followed the oral administration of potassium salts to rabbits with uranium nephritis. Similar amounts were without effect in control animals. He reported no chemical determinations of potassium in the serum or urine. Smillie's observations have frequently been cited as indications of the possibility of potassium poisoning in renal insufficiency. However, the complex extrarenal changes which occur in uranium nephritis and the peculiarly specialized character of the rabbit kidney make it improper to generalize from these experiments concerning oral potassium poisoning. There is, on the other hand, reason for minimizing the danger of toxicity from potassium in human nephritis. High concentrations of potassium in the serum are rare even in the most advanced nephritis (2), although these patients may ingest considerable amounts of meat and other foods containing potassium, and although they must continually be liberating potassium from the breakdown of tissue.

In the present study an attempt is made to ascertain whether humans or animals can be poisoned by oral administration of potassium. Potassium salts were administered to human subjects with and without renal impairment, and the concentrations of potassium in serum and urine followed at intervals thereafter. In another type of experiment, dogs whose ureters had been tied received potassium salts by stomach tube. Frequent electrocardiographic observations and chem-

1 Aided by grants from the Ella Sachs Plotz fund, the Fluid Research Fund of Yale University and the Committee on Therapeutic Research of the American Medical Association. ical determinations of potassium in serum were used for the detection and estimation of toxic effects of potassium in these animals (10).

\section{METHODS}

\section{(A) General}

The method of conducting the observations in fasting human subjects has been described elsewhere (3). Samples of urine and of serum were obtained at intervals before and after the ingestion of potassium salts. Urine specimens were collected without catheterization. Usually considerable water was given during the course of the experiment. Potassium salts were administered either in capsules, followed by water, or dissolved in tomato juice. Urea clearances were determined in all experiments, and in some, sucrose clearances were measured after preliminary intravenous injections of sucrose. Both sucrose and urea clearances vary with the glomerular filtration rate and in renal disease are reduced in about the same proportion as the filtration rate $(3,4)$. Accordingly, they may both be used as relative measures of glomerular filtration. Potassium was determined as the chloroplatinate by the method of Hald (5). Clearances were calculated by the general method previously described (3).

For the animal experiments nine dogs were employed. All experiments were carried out under nembutal anesthesia (40 mgm. per $\mathrm{kgm}$.). A tracheal cannula was inserted. Urinary excretion was suppressed by ligation of the ureters. Potassium chloride in isotonic or hypertonic solution was introduced by tube into the stomach or duodenum. Serial electrocardiograms from lead II were taken and samples of blood for potassium analysis were obtained by direct puncture of the heart at the termination of the experiment.

\section{(B) Electrocardiographic changes as criteria of potassium poisoning}

As the concentration of potassium in the serum rises, the following sequence of electrocardiographic changes is observed (6): (1) increased amplitude of the $T$ wave, (2) depression of the ST segment with development of a diphasic $\mathrm{T}$ wave, (3) disappearance of the $\mathrm{P}$ wave, (4) intraventricular block, and (5) cardiac arrest at concentrations of serum potassium of 12 to 20 m.eq. per liter. These changes, save for the last, are reversible. No one of them is, of course, characteristic; but when 
TABLE I

Fasting excretion and clearance of potassium; no salts of potassium ingested

\begin{tabular}{|c|c|c|c|c|c|c|c|c|}
\hline \multirow[b]{2}{*}{$\frac{\text { 马े }}{\text { 竞 }}$} & \multirow[b]{2}{*}{ 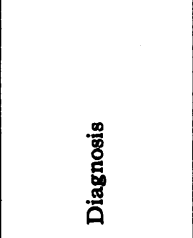 } & \multicolumn{2}{|c|}{$\underset{\text { potassium }}{\text { Serum }}$} & \multicolumn{2}{|c|}{$\begin{array}{c}\text { Urine } \\
\text { potassium }\end{array}$} & \multicolumn{3}{|c|}{ Clearances } \\
\hline & & $\stackrel{+}{\stackrel{\Xi}{E}}$ & 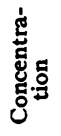 & 忑 & 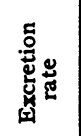 & 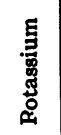 & 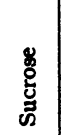 & \$. \\
\hline & & $\begin{array}{l}\min - \\
\text { utes }\end{array}$ & $\begin{array}{c}\text { m. eq. } \\
\text { per } \\
\text { liler }\end{array}$ & $\begin{array}{c}\text { min- } \\
\text { utes }\end{array}$ & $\underset{\substack{\text { per } \\
\text { minute } \\
\times 10^{3}}}{ }$ & $\begin{array}{c}c c . \\
\text { per } \\
\text { min- } \\
\text { ute }\end{array}$ & $\begin{array}{c}c c . \\
\text { per } \\
\text { min- } \\
\text { ute }\end{array}$ & $\begin{array}{c}c c . \\
\text { per } \\
\text { mix- } \\
\text { ule }\end{array}$ \\
\hline 1 & Arthritis & & & $\begin{array}{r}0-33 \\
33-65 \\
65-93\end{array}$ & $\begin{array}{l}50.2 \\
53.2 \\
35.5\end{array}$ & $\begin{array}{r}10.0^{*} \\
10.6^{*} \\
7.1^{*}\end{array}$ & $\begin{array}{l}143 \\
122 \\
122\end{array}$ & $\begin{array}{l}40 \\
76 \\
60\end{array}$ \\
\hline 2 & Diabetes & $\begin{array}{r}45 \\
128\end{array}$ & $\begin{array}{l}5.00 \\
4.60\end{array}$ & $\begin{array}{c}0-42 \\
42-95 \\
95-128\end{array}$ & $\begin{array}{l}53.9 \\
70.9 \\
43.4\end{array}$ & $\begin{array}{r}10.8 \\
14.2 \\
9.0\end{array}$ & $\begin{array}{l}111 \\
110 \\
108\end{array}$ & $\begin{array}{l}42 \\
40 \\
41\end{array}$ \\
\hline 3 & Hyperthyroidism & 112 & 5.15 & $\begin{array}{c}6-71 \\
71-115\end{array}$ & $\begin{array}{l}47.3 \\
36.9\end{array}$ & $\begin{array}{l}9.2 \\
7.4\end{array}$ & $\begin{array}{l}170 \\
126\end{array}$ & $\begin{array}{l}67 \\
55\end{array}$ \\
\hline 4 & Nephrosclerosis & $\begin{array}{r}8 \\
133\end{array}$ & $\begin{array}{l}5.00 \\
5.00\end{array}$ & $\mid \begin{array}{c}0-37 \\
37-81 \\
81-129\end{array}$ & $\begin{array}{l}42.8 \\
46.9 \\
32.8\end{array}$ & $\begin{array}{l}8.6 \\
9.4 \\
6.6\end{array}$ & $\begin{array}{l}92 \\
82 \\
68\end{array}$ & $\begin{array}{l}47 \\
36 \\
30\end{array}$ \\
\hline 5 & Pyelonephritis & $\begin{array}{r}5 \\
144\end{array}$ & $\begin{array}{l}5.40 \\
5.65\end{array}$ & $\begin{array}{c}0-36 \\
36-92 \\
92-135\end{array}$ & $\begin{array}{l}50.3 \\
46.0 \\
40.1\end{array}$ & $\begin{array}{l}9.7 \\
8.9 \\
7.1\end{array}$ & $\begin{array}{l}16 \\
18 \\
15\end{array}$ & $\begin{array}{l}9 \\
9 \\
8\end{array}$ \\
\hline
\end{tabular}

* Assuming serum potassium of 5.0 m.eq. per liter.

$\dagger$ Time from beginning of experiment.

found in sequence they are sufficiently specific to serve as criteria by which the presence and degree of cardiac potassium poisoning may be detected.

\section{RESULTS}

\section{(A) Observations on human subjects}

Five experiments, with fasting human subjects, are summarized in Table I. In Subjects 1, 2 and 3 glomerular filtration, as measured by the sucrose and urea clearances $(3,4)$, was normal ; in Subject 4 somewhat reduced, and in Subject 5 severely impaired. In all five, however, the fasting rate of excretion of potassium was approximately the same, averaging about $0.05 \mathrm{~m}$. eq. per minute, ${ }^{2}$ and varying over the extreme range of 0.03 to $0.07 \mathrm{~m}$. eq. per minute. The excretion rate was no lower in Subject 5 than in the others. Since. the serum concentration was normal in all experiments, this means that fasting potassium clearance was usually about the same in all subjects, whether

2 The average fasting excretion rate of 0.05 m.eq. per minute corresponds to $\mathbf{2 . 9}$ grams of potassium daily. On the assumption that in the breakdown of tissue $1 \mathrm{gram}$ of potassium is released for every 2.5 grams of nitrogen (2), this corresponds to $2.9 \times 2.5 \times 6.25=45$ grams of protein broken down daily. This is a reasonable figure for tissue catabolism. or not glomerular filtration was reduced. In magnitude it was about $10 \mathrm{cc}$. per minute; this was about one-twelfth or one-fifteenth of the average glomerular filtration rate in normal subjects (7), but amounted to nearly half the glomerular filtration in Subject 5. This means that in the subjects with impaired function a normal fasting excretion rate of potassium was maintained by a great decrease in the usual proportion of potassium per unit of filtrate reabsorbed by the tubules.

The response of two subjects with normal renal function to the ingestion of potassium salts is recorded in Table II A. In the first subject (1a) the rate of excretion of potassium increased over fivefold. The serum concentration rose but slightly, so that the clearance of potassium rose to an almost equal extent. In the second subject (2a) the increase is partially masked by an abnormally high fasting excretion rate of potassium, due to some unknown cause. Here too, however, an excretion rate many times the normal fasting value continued for some hours after ingestion and (since the serum concentration rose but little) was associated with a marked elevation of the potassium clearance. In spite of this increased excretion rate, elimination of the ingested potassium was slow. In Experiment 1a only about one-third was eliminated in two hours, while in Experiment $2 \mathrm{~b}$ only about three-fourths had been recovered from the urine in five hours.

The course following the administration of potassium salts in five subjects $(1 b, 2 b, 3 b, 4 b, 5 b)$ exhibiting varying degrees of renal impairment is outlined in Table II B. In these subjects, too, the rate of excretion increased definitely following the ingestion of potassium, but not as much as it did in the normal subjects of Table II A. The maximal increase in potassium concentration in the serum was about the same in nephritic as in normal subjects but the elevated concentration persisted for a longer period in the more severe nephritics. Since the initial level was a little higher in some of the nephritic subjects, the final total concentration attained was sometimes a trifle higher. However, the concentration never exceeded $8 \mathrm{~m}$. eq. per liter with doses of the size here given. Attempts to administer potassium salts in amounts greater than these were unsuccessful, since cramp-like epigastric pains followed by nausea and vomiting regularly intervened. In 
TABLE II

(A) Subjects without renal impairment; response to ingestion of potassium salts

\begin{tabular}{|c|c|c|c|c|c|c|c|c|c|c|c|c|}
\hline \multirow{2}{*}{$\underset{\text { ber }}{\text { Num- }}$} & \multirow{2}{*}{ Diagnosis } & \multicolumn{2}{|c|}{ Potassium ingested } & \multicolumn{2}{|c|}{ Serum potassium } & \multicolumn{3}{|c|}{ Urine potassium } & \multirow{2}{*}{$\begin{array}{c}\text { Total } \\
\text { amount } \\
\text { excreted }\end{array}$} & \multicolumn{3}{|c|}{ Clearances } \\
\hline & & Time & Amount & Time & $\begin{array}{c}\text { Con- } \\
\text { cen- } \\
\text { tration }\end{array}$ & Time & $\begin{array}{l}\text { Excre- } \\
\text { tion } \\
\text { rate }\end{array}$ & $\begin{array}{l}\text { Amount } \\
\text { excreted }\end{array}$ & & $\begin{array}{c}\text { Potas- } \\
\text { sium }\end{array}$ & Sucrose & Urea \\
\hline $1 \mathrm{~A}$ & Hypertension & $\begin{array}{c}\text { minutes } \\
0\end{array}$ & $\begin{array}{c}\text { m. eq. } \\
67\end{array}$ & $\begin{array}{c}\text { minutes* } \\
3 \\
68 \\
127\end{array}$ & $\begin{array}{l}\text { m. eq. } \\
\text { per } \\
\text { liter } \\
4.75 \\
5.75 \\
5.50\end{array}$ & $\begin{array}{c}\text { minutes* } \\
0-42 \\
42-80 \\
80-124\end{array}$ & \begin{tabular}{|c|} 
m. eq. per \\
minute \\
$\times 10$ \\
45.6 \\
244.0 \\
238.0
\end{tabular} & $\begin{array}{c}\text { m. eq. } \\
1.9 \\
9.3 \\
10.5\end{array}$ & m.eq. & $\begin{array}{c}c c . \\
\text { per } \\
\text { minute } \\
8.7 \\
42.3 \\
42.8\end{array}$ & $\begin{array}{c}c c . \\
\begin{array}{c}\text { per } \\
\text { minute }\end{array} \\
139 \\
208 \\
207\end{array}$ & $\begin{array}{c}c c . \\
\text { per } \\
\text { minute } \\
65 \\
94 \\
103\end{array}$ \\
\hline $2 A$ & $\begin{array}{c}\text { Hodgkin's } \\
\text { disease }\end{array}$ & $83-143$ & 100 & $\begin{array}{r}0 \\
150 \\
248 \\
376\end{array}$ & $\begin{array}{l}4.80 \\
7.65 \\
6.25 \\
5.00\end{array}$ & $\begin{array}{c}0-53 \\
53-80 \\
80-125 \\
125-240 \\
240-375\end{array}$ & $\begin{array}{l}280.0 \\
143.8 \\
224.0 \\
345.0 \\
238.2\end{array}$ & $\begin{array}{c}(14.8) \\
(3.9) \\
10.1 \\
39.7 \\
32.1\end{array}$ & 81.9 & $\begin{array}{l}58.0 \\
30.1 \\
29.3 \\
50.5 \\
42.2\end{array}$ & & $\begin{array}{r}157 \\
91 \\
95 \\
61 \\
56\end{array}$ \\
\hline
\end{tabular}

(B) Subjects with renal impairment; response to ingestion of potassium chloride

\begin{tabular}{|c|c|c|c|c|c|c|c|c|c|c|c|c|}
\hline $1 \mathrm{~B}$ & Nephrosclerosis & 134 & 67 & $\begin{array}{r}0 \\
67 \\
162 \\
211\end{array}$ & $\begin{array}{l}4.90 \\
5.00 \\
5.45 \\
6.25\end{array}$ & $\begin{array}{c}0-58 \\
58-140 \\
140-208 \\
208-270\end{array}$ & $\begin{array}{l}22.4 \\
63.5 \\
64.0 \\
61.5\end{array}$ & $\begin{array}{l}(1.3) \\
5.2 \\
4.4 \\
3.8\end{array}$ & 12 & $\begin{array}{r}4.6 \\
12.1 \\
10.2 \\
9.8\end{array}$ & $\begin{array}{l}71 \\
49 \\
71\end{array}$ & $\begin{array}{l}56 \\
32 \\
29\end{array}$ \\
\hline $2 B$ & Acute nephritis & $105-115$ & $67 \ddagger$ & $\begin{array}{r}0 \\
207 \\
246 \\
296\end{array}$ & $\begin{array}{l}6.25 \\
6.50 \\
5.90\end{array}$ & $\begin{array}{c}0-95 \\
95-202 \\
202-240 \\
240-270 \\
270-292\end{array}$ & $\begin{array}{r}45.2 \\
79.3 \\
114.3 \\
74.1 \\
68.9\end{array}$ & $\begin{array}{l}(4.2) \\
8.5 \\
4.4 \\
2.2 \\
1.5\end{array}$ & 166 & $\begin{array}{r}9.0 \\
14.1 \\
18.0 \\
11.4 \\
11.3\end{array}$ & $\begin{array}{l}36 \\
25 \\
23\end{array}$ & $\begin{array}{l}20 \\
22 \\
26 \\
16 \\
15\end{array}$ \\
\hline 3B & Acute ncphritis & $79-146$ & 107 & $\begin{array}{r}0 \\
79 \\
196 \\
232 \\
300 \\
409\end{array}$ & $\begin{array}{l}6.35 \\
6.95 \\
7.45 \\
7.65 \\
7.70 \\
7.95\end{array}$ & $\begin{array}{c}0-42 \\
42-79 \\
79-122 \\
122-189 \\
189-227 \\
227-297 \\
297-350 \\
350-406\end{array}$ & $\begin{array}{r}54.7 \\
48.9 \\
66.2 \\
83.7 \\
104.5 \\
87.0 \\
114.0 \\
89.9\end{array}$ & $\begin{array}{l}(2.3) \\
(1.8) \\
2.9 \\
5.6 \\
4.0 \\
6.1 \\
6.0 \\
5.0\end{array}$ & 29.6 & $\begin{array}{r}8.6 \\
7.9 \\
10.0 \\
11.6 \\
13.9 \\
11.3 \\
14.9 \\
11.5\end{array}$ & & $\begin{array}{r}9 \\
10 \\
13 \\
9 \\
8 \\
6 \\
12 \\
7\end{array}$ \\
\hline $4 B$ & Chronic nephritis & $\mid 106-146$ & 134 & $\begin{array}{r}0 \\
180 \\
357\end{array}$ & $\begin{array}{l}4.90 \\
6.75 \\
7.35\end{array}$ & $\begin{array}{c}0-48 \\
48-104 \\
104-135 \\
135-174 \\
174-251 \\
251-301 \\
301-357\end{array}$ & $\begin{array}{l}32.5 \\
\overline{49.0}^{8} \\
73.7^{8} \\
\overline{84.0}^{8} \\
93.3\end{array}$ & $\begin{array}{l}(1.6) \\
2.2 \mathrm{e} \\
1.5 \\
2.9 \\
6.2 \mathrm{e} \\
4.3 \\
5.2\end{array}$ & $\begin{array}{c}\text { imated } \\
22.3\end{array}$ & $\begin{array}{r}8.6 \\
\\
9.5 \\
12.5 \\
\\
12.2 \\
12.9\end{array}$ & & $\begin{array}{r}9 \\
8 \\
9 \\
9 \\
11\end{array}$ \\
\hline 5B & Chronic nephritis & $156-241$ & 94 & $\begin{array}{r}84 \\
150 \\
238 \\
326 \\
404\end{array}$ & $\begin{array}{l}5.00 \\
6.05 \\
6.70 \\
6.95 \\
7.50\end{array}$ & $\begin{array}{c}0-90 \\
90-155 \\
155-234 \\
234-322 \\
322-401\end{array}$ & $\begin{array}{r}41.3 \\
75.8 \\
99.2 \\
110.3 \\
112.0\end{array}$ & $\begin{array}{c}(3.7) \\
(4.9) \\
7.8 \\
9.8 \\
8.8\end{array}$ & 26.4 & $\begin{array}{r}8.3 \\
13.8 \\
15.6 \\
16.2 \\
15.5\end{array}$ & & $\begin{array}{l}17 \\
23 \\
24 \\
19 \\
18\end{array}$ \\
\hline
\end{tabular}

* Time from beginning of experiment.

+ Figures in parentheses are not included in the summation of the amount excreted.

$\ddagger$ Vomited.

$\$$ Collection incomplete. 
Experiment 3b "collapse," similar to that described by Smillie, occurred. The patient became very pale, sweated profusely, the pulse became rapid, the blood pressure fell, and he lost consciousness for an instant. He then vomited a small amount of fluid after which the symptoms disappeared completely and he felt entirely normal. The serum potassium was $7.70 \mathrm{~m}$. eq. per liter at the time of the attack, and continued to rise to 7.95 later, although the patient had recovered completely. This makes it unlikely that the episode was due to cardiac potassium poisoning. It appeared rather to have been a transient reflex vasodilatation in a subject with acute arterial disease, perhaps induced by gastro-intestinal irritation, i.e., a vagotonic associate of nausea and vomiting.

Since the increase in the rate of excretion of potassium is less than that in normal subjects, elimination is correspondingly delayed, so that even after five and six hours only one-quarter or less of the ingested potassium had been eliminated. Nevertheless, as has been observed, the serum concentration is only moderately elevated. The reason for this presumably lies in the mode of distribution of potassium in the body. Also, in these cases its absorption may have been greatly delayed.

The increase in concentration of potassium in the serum following the ingestion (8) or injection $(9,10)$ of potassium salts is only about one-third as great as that which would be expected were its distribution purely extracellular. In other words, about two-thirds of the absorbed potassium leaves the extracellular fluid. This amount can be accounted for on the assumption that a uniform rise of potassium concentration of the same magnitude as that in serum water occurs throughout the cellular water. However, segregation of some or all of this potassium in some particular tissue is equally consistent with the facts. Hahn, Hevesy and Rebbe (11), using a radioactive isotope of potassium, have demonstrated an absence of diffusion equilibrium between cellular and extracellular potassium. This indicates that potassium ions exchange relatively slowly across the cell membranes of the body, and so perhaps makes the hypothesis of uniform distribution in all body water somewhat less probable. The interpretation of their experiments, in which the concentration of radioactive potassium in various tissues was determined, is not entirely clear; possibly some special accumulation in bones took place. Whatever the mechanism, it is certain that the body does have the capacity to store at least two parts of potassium elsewhere for each part that accumulates in the extracellular fluid. This means that, with respect to potassium, the body has a buffer capacity by which increases in the concentration of this element in the serum, after ingestion of its salts, are minimized. The quantitative importance of this buffer mechanism may best be seen by considering a typical example. This has been done graphically in Figure 1, using data of Experiment

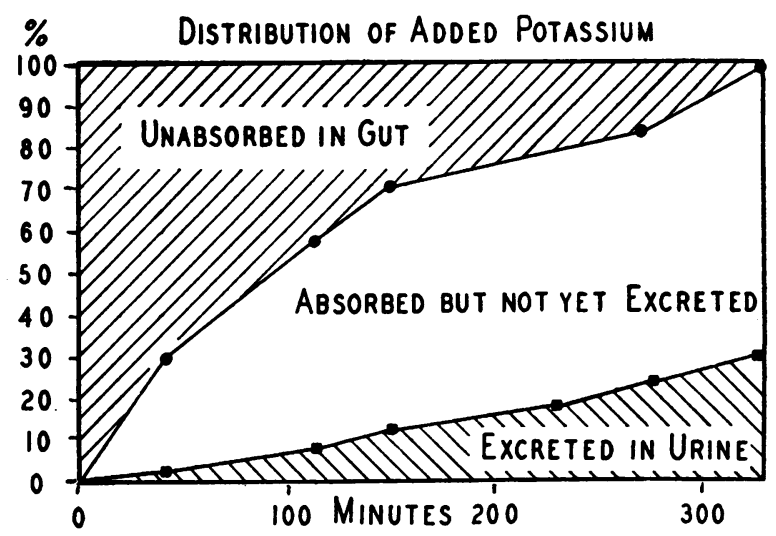

Fig. 1. Proportions of the Ingested Potassium (A) Still Unabsorbed from Gut, (b) Absorbed and PresENT IN THE Body AND (c) EXCRETEd IN THE URINE

The amount present in the urine was determined by chemical analysis. That present in the body was calculated on the assumption that one-third of the ingested potassium was present in the extracellular fluid. The increase in concentration of potassium in the serum water was multiplied by the volume of the extracellular fluid (assumed to be 15 liters), and this figure in turn multiplied by three to obtain the total amount distributed in the body. The amount still present in the gut was calculated by difference. Since the factor three is based largely on experiments with intravenous injections in dogs and in a very few human subjects, it is quite an approximate one. Therefore, these calculated values are only approximate, but serve to illustrate the several components in the system. From the data of Experiment 3b, Table II B.

$3 b$ of Table II B. Absorption from the gut is slow, being complete only after some five hours. Excretion in the urine is also very gradual. At the end of five hours the greater part of the potassium can be accounted for within the body. Be- 
cause a large proportion finds a temporary repository outside the extracellular fluid, the increase in the concentration of potassium in serum water is only about one-third as great as that of a substance limited to an extracellular distribution.

Although excretion rate is not as greatly elevated in patients with renal insufficiency as in normal subjects, it increases sufficiently to cause the clearance of potassium to rise. This enables the excess potassium to be eliminated without a great change in the potassium of serum and, although elimination is slow, it is sufficiently increased above normal so that the ingested potassium could be eliminated within twenty-four hours.

\section{Discussion of the observations on human subjects}

The experiments with human subjects which have just been described indicate the reasons for the rarity of potassium poisoning in human nephritis. In summary they are as follows:

(1) The fasting clearance of potassium is not reduced in renal disease, so that the basal excretion of potassium continues without increase in potassium in the serum.

(2) The distribution of the potassium ion beyond the confines of the extracellular fluid provides a temporary storage site for large amounts of potassium without much increase in serum concentration.

(3) The relatively slow gastro-intestinal absorption of potassium prevents transient high concentrations of potassium in the serum.

(4) Even with the most severe renal disease the clearance of potassium rises significantly above the fasting level following the ingestion of potassium salts. The associated increase in excretion rate permits the extra ingested potassium to be eliminated after some hours.

(5) It is difficult to administer amounts of potassium too great to be cared for by the storage and excretory capacities without inducing nausea and vomiting.

However, the possibility that potassium poisoning may under some circumstances occur in renal insufficiency has not been excluded. Since experiments designed to test this possibility are obviously too dangerous to attempt with human subjects, resort was had to animal experimentation.

\section{(B) Experiments with dogs}

\section{(1) Control experiments.}

Potassium salts were introduced directly into the duodenum of two normal anesthetized dogs in order to insure the most rapid possible absorption. In spite of this, the potassium of serum rose but slightly after four to ten hours, and only the earlier electrocardiographic changes appeared. Rapid absorption from the gastro-intestinal tract certainly took place under these conditions, as was apparent in experiments similar in every respect save that the ureters were obstructed. Failure to produce a notable accumulation of potassium in the body fluids appears, therefore, to have been due to rapid excretion rather than faulty absorption. Evidently, the rate at which potassium may normally be excreted by the kidneys easily equals the maximal rate of absorption from the gastrointestinal tract. It is therefore reasonable to conclucle that fatal poisoning from oral ingestion of potassium cannot occur in the presence of normal renal function.

(2) Experiments with dogs with ligated ureters.

(a) Delay in absorption of potassium salts introduced into the stomach.

When solutions of potassium chloride were introduced into the stomach by tube, electrocardiographic or chemical evidences of potassium poisoning usually failed to develop for an hour or more. Pressure on the abdomen forced back through the stomach tube as much fluid as had been administered, indicating that the absence of potassium effects was due to failure of absorption. The cause for this was at once apparent on opening the abdomen. The pylorus was so tightly contracted that even with vigorous manual manipulation it was impossible to force the stomach contents past it into the duodenum.

The fluid was permitted to remain in the stomach of three animals. One animal showed the first electrocardiographic signs of potassium poisoning after thirty-five minutes, and died after an hour. The other two still survived at the end of ten hours, but with unmistakable electrocardiographic changes characteristic of pre-terminal potassium poisoning and with concentrations of potassium in the serum of 10.1 and $10.9 \mathrm{~m}$. eq. per liter, respectively. It seems probable that the 
long survival was due to cessation of absorption of potassium due to circulatory failure after the potassium concentration had risen to a level nearly, but not quite, sufficient to produce death. There is other evidence that such circulatory failure does occur (12). (b) Duodenal administration of potassium. Potassium chloride was administered by means of a tube passed through the pylorus via a gastrostomy in order to avoid delay in absorption due to pylorospasm. In three experiments this was done after a previous unsuccessful attempt
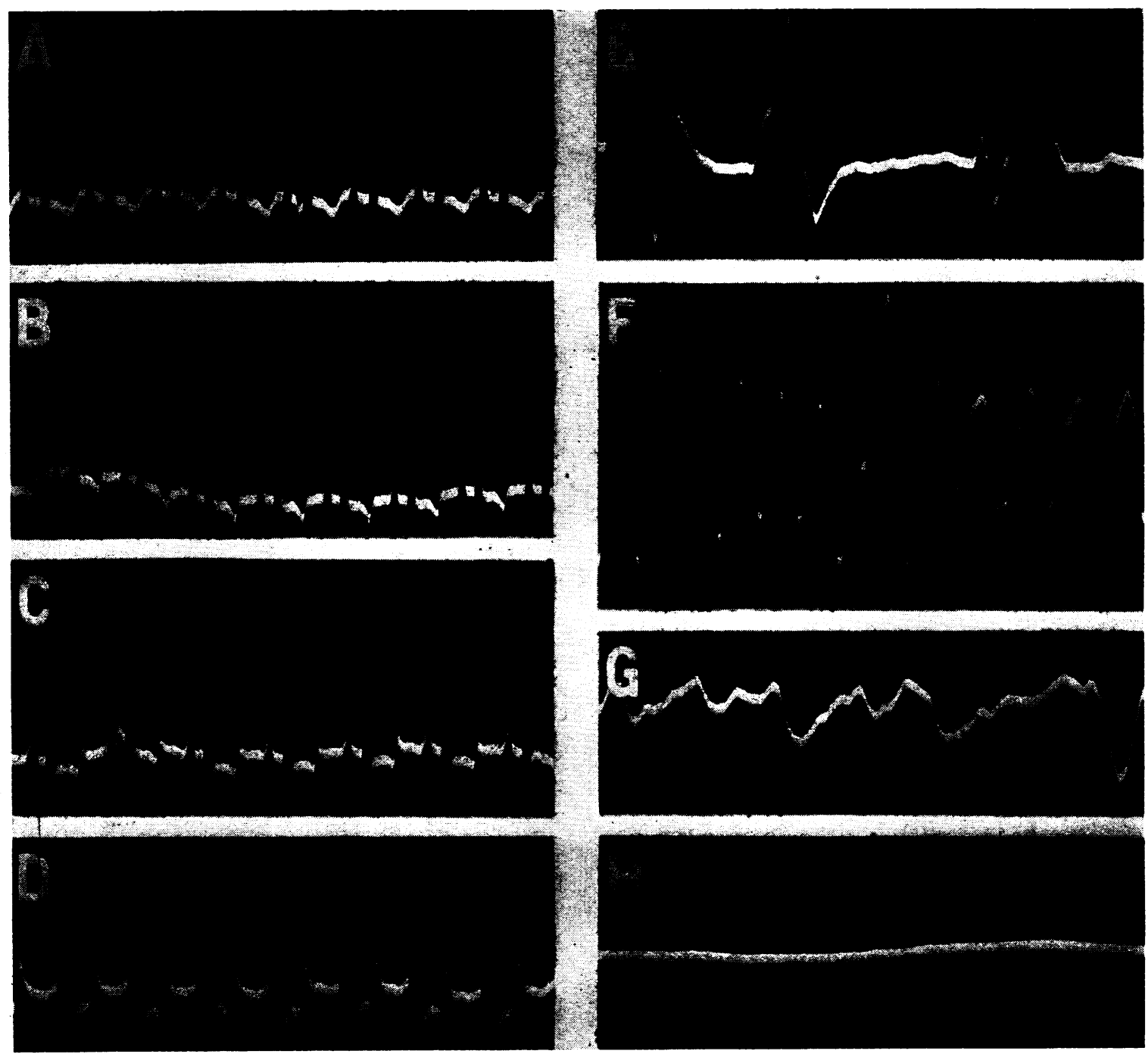

Fić. 2. Serial Electrocardiograms Obtained in a Dog With ligated Ureters Following the Administration of Twice Isotonic $\mathrm{KCl}$ Solution by Tube into the Duodenum

All records from lead II. Dog, $7.5 \mathrm{kgm}$.

(A) Control.

(B) No change seventeen minutes after 1 liter of solution before ureters were tied.

(C) Depression of ST segment and beginning diphasic T wave fifteen minutes after ligation of ureters and administration of another liter of $\mathrm{KCl}$.

(D) Disappearance of $\mathrm{P}$ waves, slight intraventricular block, marked ST segment depression, diphasic $\mathrm{T}$ wave thirty-five minutes after ureteral ligation.

(E) Marked intraventricular block and some slowing fifty minutes after ligation.

(F) and (G) Sudden ventricular flutter, followed within two minutes by coarse ventricular fibrillation.

(H) Arrest two minutes later. Concentration of potassium in serum 13.0. 
to bring about absorption by introduction into the stomach, while in three others no such prior attempt had been made. Prompt and vigorous purgation occurred in all three experiments, and much of the solution administered was quickly lost in this way. All six animals died within a few minutes to an hour, depending on the rate at which the potassium chloride was administered. That death was due to cardiac potassium poisoning appears certain from the characteristic sequence of electrocardiographic changes in each instance (Figure 2, $\mathrm{A}$ to $\mathrm{E}$ ), and from the high concentrations of potassium in the blood just before death. These were $9.8,10.8,12.4,13.0,13.0$, $14.4 \mathrm{~m}$. eq. per liter, respectively, and fall in or just below the range associated with cardiac arrest from intravenous potassium (6).

In a few of these experiments exitus did not occur following cardiac slowing and arrest. Instead, the rate was maintained for some time in the face of increasing intraventricular block until suddenly ventricular flutter and coarse fibrillation appeared (Figure 2, F, G). It seems reasonable to suppose that in these experiments circulatory failure occurred as the result of intraventricular block, delaying further absorption of potassium so that the final stages of slowing and arrest did not appear.

\section{DISCUSSION}

Evidently, it is possible for fatal poisoning from oral potassium to occur under certain experimental conditions. The essential conditions are suppression of urinary secretion and direct introduction of the potassium solution into the duodenum. In the dog, at least, this second condition is difficult of attainment after ordinary oral administration owing to pylorospasm. The relatively slow absorption of potassium and the severe epigastric pain, cramps and vomiting observed in human subjects after potassium salts are administered strongly suggest that in man, too, pylorospasm may occur. No pylorospasm occurred in control experiments in which water or normal saline was introduced into the stomach of a dog with ligated ureters. This spasm after potassium chloride is therefore not simply a response of the pylorus of such an animal to the ingestion of any fluid. However, there is no evidence that the production of pylorospasm is a unique property of the potassium ion, as other irritant salts were not tested.

The animal experiments, therefore, indicate that, while oral potassium poisoning may occur, the conditions necessary for its production are not likely to occur in human subjects with nephritis. In a deeply anesthetized animal with complete anuria, enough potassium may eventually pass the pyloric sphincter to cause death. In man, comparable doses are, of course, not given; and even with smaller amounts vomiting acts to remove a great proportion of the material administered. Moreover, a distinction must be drawn between the situation in nephritis and that in complete anuria. In the nephritic patient renal function is rarely completely suppressed. The rate of excretion of potassium, though reduced, is sufficient to eliminate that coming from tissue breakdown, as well as a certain excess. Consequently, the small amounts passing the sphincter and absorbed from the duodenum can be gradually eliminated, while the distribution in the body minimizes the transient increase in concentration of circulating potassium. On the other hand, in complete anuria (such as that following mercury poisoning), there is obviously much more possibility of potassium poisoning, since the delays of absorption and the wide distribution are of temporary value only. Indeed, in animals with complete urinary obstruction, gradual elevation of serum potassium due to tissue breakdown is the rule (13). The danger of giving even small amounts of potassium by mouth under such circumstances is self-evident.

\section{CONCLUSION}

1. Cardiac death due to potassium absorbed from the gastro-intestinal tract can be produced experimentally in dogs whose ureters have been tied.

2. Direct introduction of potassium salts into the stomach induces spasm of the pylorus, preventing absorption and delaying death. Rapid death occurs when potassium salts are introduced directly into the duodenum of animals with ligated ureters.

3. It is unlikely that the conditions necessary for fatal poisoning by oral potassium administra- 
tion can occur in patients with nephritis so long as urine is being excreted. The relatively slow absorption, the vomiting when large doses are given, the mode of distribution in the body and, most important of all, the continued ability of the most severely damaged nephritic kidney to excrete potassium all combine to make such poisoning very difficult to bring about.

4. Poisoning from oral administration of potassium is a more distinct possibility with complete anuria from any cause.

\section{BIBLIOGRAPHY}

1. Smillie, W. G., Potassium poisoning in nephritis. Arch. Int. Med., 1915, 16, 330.

2. Peters, J. P., and Van Slyke, D. D., Quantitative Clinical Chemistry, Vol. I, Interpretations. Williams and Wilkins, Baltimore, 1931.

3. Winkler, A. W., and Parra, J., The measurement of glomerular filtration. The creatinine, sucrose and urea clearances in subjects without renal disease. J. Clin. Invest., 1937, 16, 859.

4. Winkler, A .W., and Parra, J., The measurement of glomerular filtration. The creatinine, sucrose and urea clearances in subjects with renal disease. J. Clin. Invest., 1937, 16, 869.
5. Hald, P. M., The determination of the bases of serum and whole blood. J. Biol. Chem., 1933, 103, 471.

6. Winkler, A. W., Hoff, H. E., and Smith, P. K., Electrocardiographic changes and concentration of potassium in serum following intravenous injection of potassium chloride. Am. J. Physiol., 1938, 124, 478.

7. Smith, H. W., The Physiology of the Kidney. Oxford University Press, New York, 1937.

8. Bourdillon, J., Distribution in body fluids and excretion of ingested ammonium chloride, potassium chloride, and sodium chloride. Am. J. Physiol., 1937, 120, 411.

9. Wilde, W. S., The distribution of potassium in the cat after intravascular injection. J. Biol. Chem., 1939, 128, 309.

10. Winkler, A. W., and Smith, P. K., The apparent volume of distribution of potassium injected intravenously. J. Biol. Chem., 1938, 124, 589.

11. Hahn, L. A., Hevesy, G. C., and Rebbe, O. H., Do potassium ions inside the muscle cells and blood corpuscles exchange with those present in the plasma? Biochem. J., 1939, 33, 1549.

12. Hoff, H. E., Smith, P. K., and Winkler, A. W., The relation of blood pressure and concentration in serum of potassium, calcium and magnesium. Am. J. Physiol., 1939, 127, 722.

13. Nicholson, W. M., and Schechter, A. J., Cardiac arrhythmia after bilateral ureteral ligation in the dog. Bull. Johns Hopkins Hosp., 1937, 60, 346. 